\title{
Laadukkaan nurmen fosforitalous ja -lannoitus ympäristöä hoitaen
}

\author{
Liisa Pietola ${ }^{1)}$ ja Perttu Virkajärvi ${ }^{2)}$ \\ ${ }^{1)}$ Yara International ASA, Mechelininkatu 1a, 00180 Helsinki, liisa.pietola@yara.com \\ 2) MTT Kotieläintuotannon tutkimus, Halolantie 31 A, 71750 Maaninka, perttu.virkajarvi@mtt.fi
}

\section{Tiivistelmä}

Nurmien ongelmana on liukoinen fosfori, jota huuhtoutuu nurmen pinnasta. Huuhtoutumisen riski kasvaa korkean fosforitilan maissa ja etenkin pintalannoituksen jälkeen. Toisaalta laadukas sato vaatii fosforitilaltaan hyvän tai vähintään tyydyttävän kasvualustan. Kriittisen rajan tarkempi arvio vaatii lisätutkimuksia, sillä suomalaiset nurmien fosforilannoituskokeet on pääsääntöisesti tehty joko fosforiluokaltaan heikoissa $\left(\mathrm{P}_{\mathrm{AAc}} \leq 10 \mathrm{mg} / \mathrm{l}\right)$ tai arveluttavan korkeissa luokissa $\left(\mathrm{P}_{\mathrm{AAc}}>50\right)$.

Joka tapauksessa ravinnehuuhtoutumisen vähentäminen vaatii muita keinoja kuin maan köyhdyttämisen kohti heikkoa fosforitilaa. Jotta nurmet saisivat tarvitsemansa fosforin ilman maan pintakerroksen fosforipitoisuuden nostamista ja ympäristöhaittoja, nurmien pintalannoituksesta pitäisi luopua ja fosfori pitäisi voida jakaa kasvukausille ja maanpintaa syvemmälle muulla tavoin. MTT ja Yara Suomi Oy:n yhteistyönä on tutkittu nurmen eri fosforilannoitusvaihtoehtoja Maaningalla vuodesta 2003: Kenttäkokein selvitettiin, olisiko fosfori mahdollista antaa varastoon käyttämällä hidasliukoista lannoitetta. Toisena vaihtoehtona tutkittiin lyhytkiertonurmea, jolloin pintamaa ja sen fosfori voitiin muokata syvempään kerrokseen normaalikäytäntöä useammin. Kolmantena vaihtoehtona seurattiin karjanlannan fosforin riittävyyttä. Kenttäkoe perustettiin hietamaahan, jonka $\mathrm{P}_{\mathrm{AAc}}$ oli $20 \mathrm{mg} / \mathrm{l}$.

Koko nurmikierron lannoituksen antaminen varastolannoituksena kerralla nurmea perustettaessa ei ratkaissut ongelmaa, sillä perustamisessa annettu fosfori ei riittänyt viimeisille nurmivuosille. Hidasliukoinen varastofosforilannoitus ja normaali varastofosforilannoitus eivät juuri poikenneet toisistaan. Varastolannoituksen vaikutus näkyi kohonneina fosforipitoisuuksina syksyn maanäytteissä, mikä ei ole tavoiteltavaa. Myöskään lyhytkiertonurmi ei tarjonnut ratkaisua fosforin huuhtoutumisen estämiseksi. Naudanlannan fosfori ei yksin riittänyt säilyttämään maan fosforitilaa. Viiden vuoden tarkasteluvälillä havaittiin, että intensiivisessä nurmiviljelyssä muokkauskerroksen fosforitila laski negatiivisella fosforitaseella tasolta $20 \mathrm{mg} / 1\left(\mathrm{P}_{\mathrm{AAc}}\right)$ tasolle $15 \mathrm{mg} / 1$. Pintakerroksen $(0-2,5 \mathrm{~cm})$ fosforitila ei laskenut vastaavasti vaan fosforin rikastuminen pintaan näkyi etenkin varastolannoitetuissa koeruuduissa.

Tutkimus antaa viitteitä siitä, että mikäli muokkauskerroksen fosforitilaa ei köyhdytetä liikaa, nurmivuosien pintalannoituksesta voidaan ajoittain luopua sadon laadun ja määrän siitä kärsimättä. Ympäristön kannalta olisi edullisinta, että nurmivuosien lannoituksessa fosfori sijoitettaisiin kasvavaan nurmeen. Maan rakenteeseen on muistettava kiinnittää huomiota edelleenkin: Irtovesi maan pinnassa johtaa aina liukoisen fosforin huuhtoutumiseen kasviaineksesta vaikka maan fosforivarastot olisivat vähäiset ja/tai maata ei lannoitettaisi ollenkaan.

Asiasanat: Fosfori, Lannoitus, Nurmi, Vesiensuojelu 


\section{Johdanto}

Nurmien fosforihuuhtoumasta tyypillisesti yli puolet on liukoista fosforia, jota huuhtoutuu varsinkin tiiviin kivennäismaan pinnasta pintalannoituksen jälkeen. Laidunnurmilla liuenneen fosforin osuus kokonaisfosforista voi olla jopa 80-90 \% (Saarijärvi ym. 2006). Fosforia huuhtoutuu kasviaineksesta varsinkin ensimmäisten pakkasten jälkeen (Uusi-Kämppä ym. 2000; Räty et al. 2009). Liukoisen fosforin huuhtoutumisen riski maa-aineksesta kasvaa korkean fosforitilan maissa eli olosuhteissa, joissa fosforin pidätyspaikat maassa täyttyvät (Turtola ja Yli-Halla 1999).

Jätevesien suurin sallittu liukoisen fosforin pitoisuus on $0,5 \mathrm{mg} / \mathrm{l}$. Pelto-oloissa tämä konsentraatio saavutetaan turvemailla asetaattiuuttoisella viljavuusluvulla $\left(\mathrm{P}_{\mathrm{AAc}}\right) \quad 14 \mathrm{mg} / \mathrm{l}$, kivennäismailla viljavuusluvulla 30-40 mg/l (Sippola ja Saarela 1992). Laidunnurmilla huuhtoutuvan fosforin määä kasvaa melko suoraviivaisesti maan pintakerroksen (0-2 cm) fosforipitoisuuden kasvaessa (Saarijärvi ym. 2006). Pitkäaikaisten kasvustojen pintakerroksen fosforipitoisuus kasvaa lannoittamattakin, koska karikkeen fosfori kertyy maan pintaan, mikä on todettu pitkäaikaisissa suojavyöhyketutkimuksissa (Räty ym. 2009). Ympäristövaikutusten kannalta ratkaisevaa on siten nurmen pintakerros ja siihen sitoutunut tai lannoitettu fosfori, eikä maan fosforivarannot sinänsä, korkeita ja arveluttavan korkeita P-luokkia lukuun ottamatta.

Edellä kuvatun perusteella ensimmäinen keino vähentää fosforin huuhtoutumista nurmilta on alentaa pellon pintakerroksen fosforipitoisuutta. Toisaalta, jottei suuria fosforimääriä tarvitsisi levittää nurmivuosina maan pintaan, juuristovyöhykkeen muissa kerroksissa pitäisi olla varastossa fosforia sadon rakennusta varten. Fosforinpuute ja siihen linkittynyt muiden ravinteiden tehoton otto vaikuttavat sadon määrään ja laatuun. Jotta nurmet saisivat tarvitsemansa fosforin ilman ympäristöhaittoja, nurmien pintalannoituksesta pitäisi luopua ja fosfori pitäisi voida jakaa kasvukausille muulla tavoin.

MTT:n Maaningan tutkimusasemalla on tutkittu eri vaihtoehtoja vuodesta 2003 yhteistyössä Yara Suomi Oy:n kanssa. Tässä kirjoituksessa esitetään tutkimuksen keskeiset tulokset lähinnä vuoden 2008 osalta, tarkastellaan maan fosforitilan kehitystä koko koejakson ajalta sekä pohditaan ympäristöystävällisen nurmiviljelyn pelisääntöjä yleisemmin. Tutkimus edustaa fosforiluokkaa hyväkorkea (aluksi $20 \mathrm{mg} / \mathrm{l}$ ), ja poikkeaa siten aikaisemmista nurmien fosforiporraskokeista, jotka on tehty lähinnä heikoissa $\left(\mathrm{P}_{\mathrm{AAc}}<10 \mathrm{mg} / \mathrm{l}\right)$ tai arveluttavan korkeissa $(>50 \mathrm{mg} / \mathrm{l})$ muokkauskerroksen fosforiluokissa.

\section{Aineisto ja menetelmät}

Kenttäkokeen tarkoituksena oli selvittää voidaanko fosfori mahdollista antaa varastoon käyttämällä hidasliukoista lannoitetta (käsittely 4, taulukko 1). Toisena vaihtoehtona tutkittiin lyhytkiertonurmea, jolloin pintamaa ja sen fosfori voitiin muokata syvempään kerrokseen normaalikäytäntöä useammin (7). Kolmantena vaihtoehtona seurattiin karjanlannan fosforin riittävyyttä $(5,6)$. Verranteena oli viljely ilman fosforilannoitusta (1) sekä normaalikäytäntö (2) jossa perustamisvuonna 2003 annettiin $25 \mathrm{~kg} / \mathrm{ha}$ fosforia ja kunakin nurmivuonna annettiin keväisin $10 \mathrm{~kg}$ /ha fosforia väkilannoitteena. Toisen nurmijakson aikana ympäristötukiehdot olivat muuttuneet ja niinpä koejäsen sai perustamisen yhteydessä $20 \mathrm{~kg} / \mathrm{ha}$ fosforia ja nurmivuosina $8 \mathrm{~kg} / \mathrm{ha}$. Väkilannoitteena annettu fosfori annettiin kaksoissuperfosfaattina. Hidasliukoiset fosforilannoitteet olivat Yara Suomi Oy:n kehittämiä koe-eriä. Koenurmena oli timotei-nurminataseosnurmi ja perustaminen tehtiin kokoviljana korjattuun ohrakasvustoon (2003 ja 2007). Nurmi korjattiin kahdesti kasvukaudessa ja sen typpilannoitus oli $100+100 \mathrm{~kg} / \mathrm{ha} \mathrm{N}$ ja suositusten mukainen kaliumlannoitus. Eri käsittelyistä mitattiin sato, sadon laatu, ravinnetase sekä maan fosforivarantojen muutokset (viljavuusfosfori $\mathrm{P}_{\mathrm{AAc}}$ sekä vesiliukoinen $\mathrm{P}\left(\mathrm{P}_{\mathrm{H} 2 \mathrm{O}}\right.$ 1:60) maan eri syvyyksissä. Kokeet perustettiin MTT:n Maaningan tutkimusaseman multavalle karkealle hietamaalle, jonka pH oli 6.1 vuonna 2003, jolloin muokkauskerroksen fosforitila oli $20 \mathrm{mg} / 1$ (P AAc; Viljavuusluokka tyydyttävä). Toisen koejakson alussa koejäseniin tehtiin lieviä muutoksia siten, että koejäsen no 6 lannoitettiin fosforin osalta lietelannalla myös satovuosina (aiemmin satovuosina $0 \mathrm{P}$ ). Lyhytkiertonurmi (no 7) lopetettiin ja korvattiin uudella hidasliukoisella P-lannoitteella. Vuonna 2008 oli menossa toisen nurmikierron ensimmäinen nurmivuosi (Taulukko 1). 


\section{Tulokset ja tulosten tarkastelu}

Koealueen hietamaan fosforitila oli niin hyvä $\left(20 \mathrm{mg} / 1 \mathrm{P}_{\mathrm{AAc}}\right)$, että eri lannoitusvaihtoehtojen sadot eivät poikenneet toisistaan edes koesarjan kuudentenakaan vuonna (2008; Taulukko 1). Sen sijaan nurmen fosforipitoisuudessa näkyi jo eroja. Etenkin toisessa niitossa koko koejaksolla ilman fosforilannoitusta oleva koejäsen erottui alhaisimman fosforipitoisuutensa vuoksi. Sinänsä havaittu pitoisuus ei ole kovin alhainen verrattuna esimerkiksi rehutaulukoiden antamaan vaihteluväliin $(2,5-3,5 \mathrm{~g} / \mathrm{kg} \mathrm{ka}$, nurmiheinät, jälkikasvu; MTT 2006) eikä ole mitenkään liian alhainen märehtijöiden ruokinnan kannalta. Alhaisempi fosforipitoisuus näkyi myös fosforipoistumassa niitoittain tarkasteltuna, mutta vuoden kokonaispoistumassa ero ei ollut enää merkitsevä. Merkillepantavaa on korkea fosforipoistuman taso riippumatta käytetystä lannoituksesta: esimerkiksi suositusten mukaan lannoitettu koejäsen (no 2) sai siis vain $8 \mathrm{~kg} / \mathrm{ha}$ fosforia tutkimusvuonna. Hidasliukoinen varastofosforilannoitus ja normaali varastofosforilannoitus eivät juuri poikenneet toisistaan. Naudanlannan fosfori ja maan reservit riittivät tuottamaan hyvän nurmisadon, sillä 0 -ruutujen ja lietekoejäsenten sato ei ollut alhaisempi kuin suositusten mukaan tai varastolannoitettujen koejäsenten sato.

Taulukko 1. Eri fosforilannoitusvaihtoehtojen vaikutus säilörehunurmen rehuyksikkösatoon (RY-sato), nurmen fosforipitoisuuteen (P) ja fosforinottoon (Potto) niitoittain ja yhteensä vuoden 2008 aikana.

\begin{tabular}{|c|c|c|c|c|c|c|c|c|c|}
\hline & & \multicolumn{3}{|c|}{ Niitto 1} & \multicolumn{3}{|c|}{ Niitto 2} & \multicolumn{2}{|c|}{ Kokonaissato } \\
\hline No & P-lannoitus & RY-sato & $\mathbf{P}$ & Potto & RY-sato & $\mathbf{P}$ & Potto & RY-sato & Potto \\
\hline & perustaminen/nurmivuodet & ry/ha & $\mathrm{g} / \mathrm{kg} \mathrm{ka}$ & $\mathrm{kg} / \mathrm{ha}$ & ry/ha & $\mathrm{g} / \mathrm{kg} \mathrm{ka}$ & $\mathrm{kg} / \mathrm{ha}$ & ry/ha & $\mathrm{kg} / \mathrm{ha}$ \\
\hline 1 & P 0/0* & 5012 & 3.0 & 15.8 & 4068 & 2.4 & 11.4 & 9080 & 27.2 \\
\hline 2 & P norm/norm & 5039 & 3.2 & 17.3 & 4179 & 2.6 & 12.8 & 9218 & 30.1 \\
\hline 3 & P varastolann./0 & 4965 & 3.2 & 17.0 & 4039 & 2.6 & 12.0 & 9004 & 29.0 \\
\hline 4 & P varasto- hidas $/ 0$ & 4879 & 3.2 & 16.7 & 4281 & 2.5 & 12.6 & 9160 & 29.3 \\
\hline 5 & P liete/0 & 4847 & 3.0 & 15.3 & 4484 & 2.6 & 13.8 & 9331 & 29.1 \\
\hline 6 & P liete/liete & 4894 & 3.0 & 15.5 & 4201 & 2.8 & 13.4 & 9094 & 28.9 \\
\hline 7 & $P$ varasto hidas II/0 & 4860 & 3.4 & 17.5 & 4196 & 2.8 & 13.6 & 9057 & 31.2 \\
\hline & Keskimäärin & 4928 & 3.1 & 16.4 & 4207 & 2.6 & 12.8 & 9135 & 29.6 \\
\hline & SEM & 96 & 0.09 & 0.49 & 146 & 0.08 & 0.59 & 160.30 & 0.862 \\
\hline & P-arvo & 0.696 & 0.023 & 0.022 & 0.39 & 0.032 & 0.081 & 0.815 & 0.116 \\
\hline
\end{tabular}

*P $0 / 0=0 \mathrm{~kg} / \mathrm{ha} / \mathrm{v}$ perustettaessa, $0 \mathrm{~kg} / \mathrm{ha}$ nurmivuosina; $\mathrm{P}$ norm $/ \mathrm{norm}=$ suositusten mukainen $\mathrm{P}$ lannoitus perustettaessa ja nurmivuosina; $\mathrm{P}$ varastolann $/ 0=$ varastolannoitus nurmea perustettaessa ja $0 \mathrm{~kg} / \mathrm{ha} / \mathrm{v}$ nurmivuosina; $\mathrm{P}$ varasto-hidas $/ 0=$ varastolannoitus hidasliukoisella lannoitteella ja $0 \mathrm{~kg} / \mathrm{ha} / \mathrm{v}$ nurmivuosina; $\mathrm{P}$ liete $/ 0=$ perustamisvaiheen lietteessä (40 tn/ha) tuleva $\mathrm{P}(7 \mathrm{~kg} / \mathrm{ha} \mathrm{P})$ mullattuna ja $0 \mathrm{~kg} / \mathrm{ha} / \mathrm{v} \mathrm{P}$ nurmivuosina; $\mathrm{P}$ liete/liete = perustamisvaiheen lietteessä $(40 \mathrm{tn} / \mathrm{ha})$ tuleva $\mathrm{P}(7 \mathrm{~kg} / \mathrm{ha} \mathrm{P}) \mathrm{ja}$ nurmivuosina lietettä n $20 \mathrm{tn} / \mathrm{ha}$ (vastaa $9 \mathrm{~kg} / \mathrm{ha} \mathrm{P}$ ) pintaan.

Fosforilannoitusvaihtoehtojen erot näkyivät huomattavasti selvemmin maassa kuin nurmessa. Varastolannoituksen vaikutus näkyi kohonneina fosforipitoisuuksina syksyn maanäytteissä, etenkin uusimisvuoden 2007 syksyllä, mikä ei ole tavoiteltavaa. Osaltaan tähän vaikuttaa käytetty lannoitustekniikka: lannoite levitettiin maan pintaan ja mullattiin äestämällä. Tiloilla käytetty sijoituslannoitus todennäköisesti alentaa paremmin juuri pintakerroksen pitoisuutta. Myöskään lyhytkiertonurmi (koejäsen 7) ei tarjonnut ratkaisua maan pintakerroksen fosforipitoisuuden alentamiseksi, sillä ero pintakerroksen fosforiluvun ja koko kyntökerroksen fosforiluvun välillä on varsin pieni. Tutkimuksessa havaittiin, että intensiivisessä nurmiviljelyssä fosforitila laski varsin nopeasti, etenkin kyntökerroksessa (Kuvat $1 \mathrm{ja}$ 2). Ilman fosforilannoitusta jääneiden koeruutujen maan fosforitila laski 6 vuoden aikana noin $7 \mathrm{mg} / \mathrm{l}$, mikä johtui suuresta negatiivisesta fosforitaseesta kokeen aikana (-124 $\mathrm{kg} / \mathrm{ha})$. 


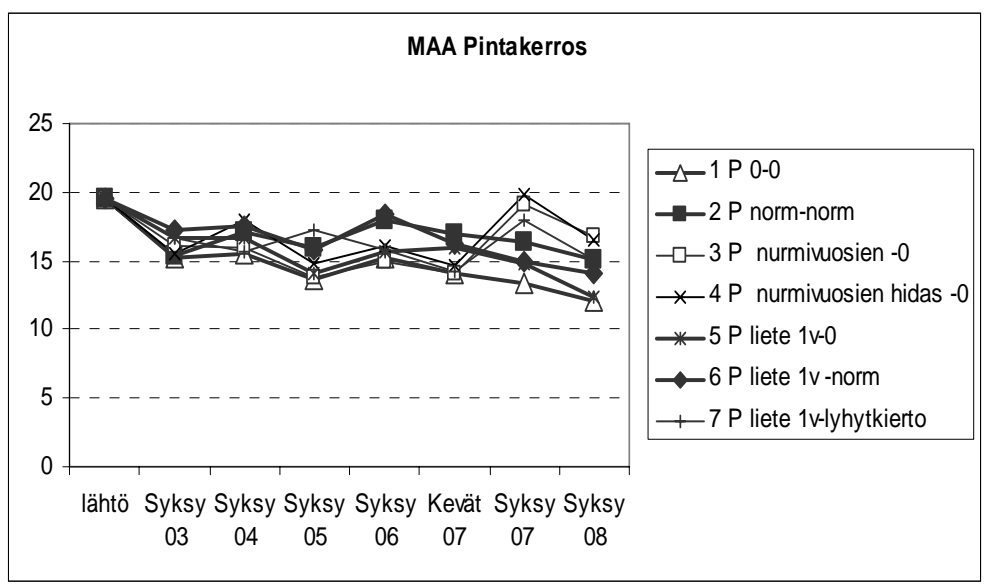

Kuva 1. Maan viljavuus-P:n ( $\left.\mathrm{P}_{\mathrm{AAc}}, \mathrm{mg} /\right)$ kehittyminen maan 0-2,5 cm.n syvyydessä Maaningan nurmen lannoituskäsittelyissä. Vuonna 2007 nurmi perustettiin uudestaan ja siksi näytteet otettiin sekä keväällä (=vanhan nurmen loppuhavainnot) että syksyllä (=uuden nurmen alkuhavainnot).

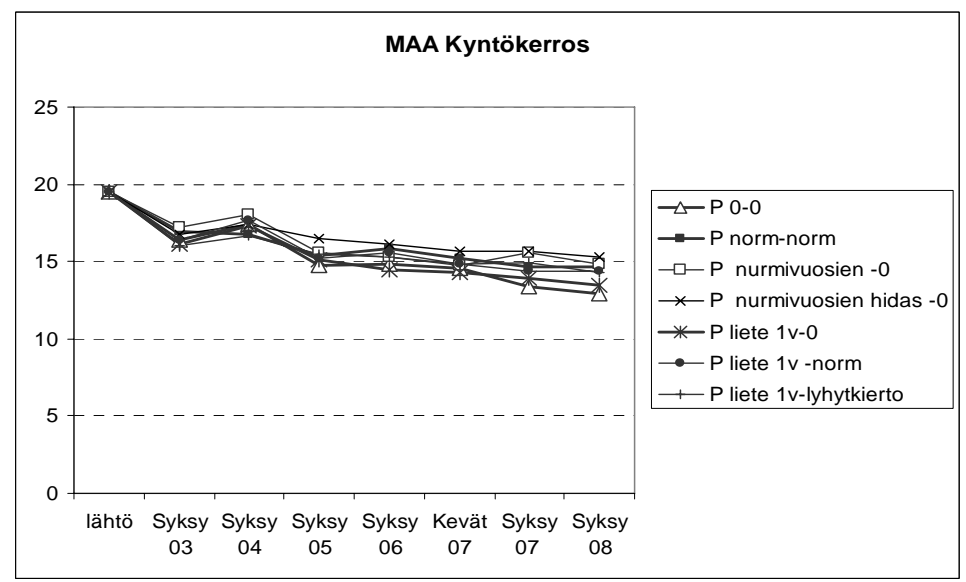

Kuva 2. Maan viljavuus-P:n ( $\left.\mathrm{P}_{\mathrm{AAc}}, \mathrm{mg} /\right)$ kehittyminen maan Kyntökerroksessa Maaningan nurmen lannoituskäsittelyissä. Vuonna 2007 nurmi perustettiin uudestaan ja siksi näytteet otettiin sekä keväällä (=vanhan nurmen loppuhavainnot) että syksyllä (=uuden nurmen alkuhavainnot).

Koeaineistosta nähdään, että myös suositusten mukaan lannoitettujen koejäsenten maan P-luku ei säily lähtötasolla vaan alenee. Onkin odotettavissa, että maan P-tilan yhä alentuessa ilman fosforia jääneiden ruutujen sato jää lannoitettuja alemmaksi.

Kriittisen maan fosforitilan arvioon saadaan lisää aineistoa Maaningan kokeen jatkuessa sekä MTT Siikajoelle perustetusta rinnakkaiskokeesta. Vanhat Suomen nurmikokeet on pääsääntöisesti tehty maille, joille P-luku on ollut alle $10 \mathrm{mg} / \mathrm{l}$. Nämä vanhat nurmikokeet (Saarela ym. 1995) edustavat aineistoa, joissa P-lukujen vaihtelu on samalla koepaikkojen ja maalajien vaihtelua. Poikkeuksena ovat Jokioisten kokeet arveluttavan korkeilla P-luvuilla (30-50 mg/l), joissa ei saatu fosforivastetta sekä Mouhijärven kokeet hiesusavimaalla, jonka $\mathrm{P}_{\mathrm{AAC}}$ oli $15-19 \mathrm{mg} / \mathrm{l}$ ja jossa fosforilannoituksella saatiin vastetta. Heikot $\mathrm{P}-$ luvut sijoittuvat hietamaille (Mikkeli, Toholampi) ja alhainen keskitaso eloperäiselle maalle (Vaala, $\mathrm{P}_{\mathrm{AAC}}$ $8 \mathrm{mg} / \mathrm{l})$ (Kuva 3). 


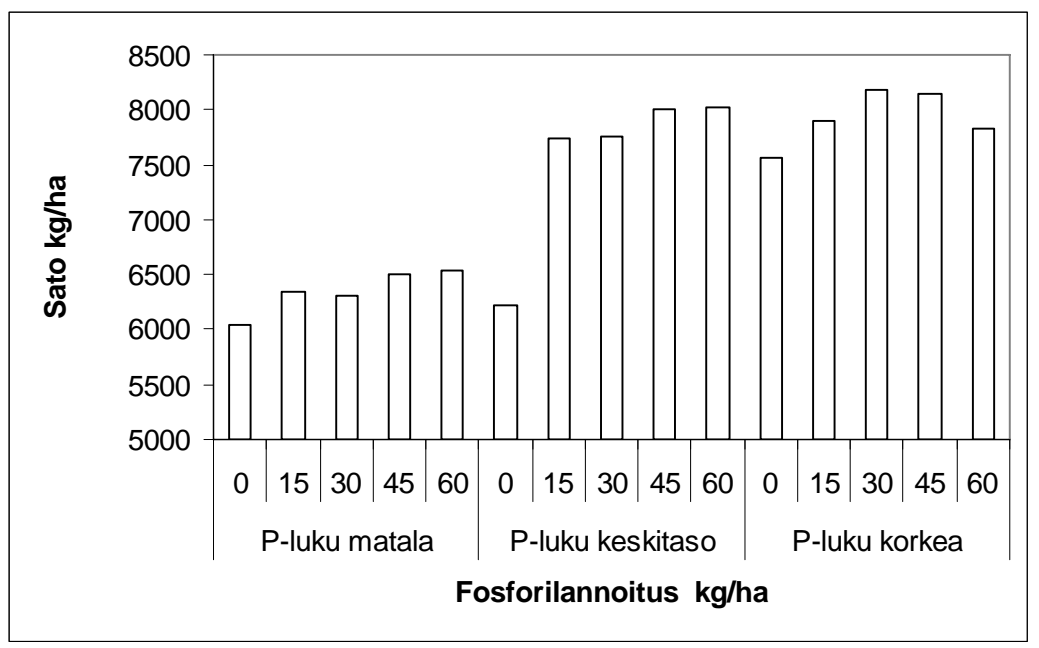

Kuva 3. Nurmisatojen riippuvuus fosforilannoitustasosta $(\mathrm{kg} / \mathrm{ha})$ ja maan P-tilasta MTT:n kenttäkokeissa, jossa eri Ptasot peräisin erilaisilta maalajeilta ja paikkakunnilta: Matalaa tasoa edustaa Toholampi (hieta, $\mathrm{P}_{\mathrm{AAc}} 8$ ), keskitasoa Vaala (multamaa, $\mathrm{P}_{\mathrm{AAc}} 8$ ) ja korkeaa Mouhijärvi (hiesusavi, $\mathrm{P}_{\mathrm{AAc}} 15$ ). Sato viiden vuoden keskiarvona vuosilta 197981 ja 1985-86, jolloin kaikista koepaikoista saatu aineistoa samoina vuosina (ref. Saarela ym. 1995).

Saarelan $(1988,1997)$ mukaan maan P-luvun ollessa alle $10 \mathrm{mg} / \mathrm{l}$ vanhemmat nurmet reagoivat voimakkaammin fosforilannoitukseen kuin nuoret nurmet. Tämän perusteella fosforilannoitus kannattaa aloittaa kolmannen vuoden nurmista. Jos nämä kynnetään syksyllä, kolmantena vuonna annettu pintafosfori sekoittuu maan sisään, jossa se ei enää ole alttiina huuhtoutumiselle, ainakaan jos eroosio on vähäistä.

Kokeen maa-analyysituloksista nähdään myös, ettei lypsykarjatilalla ole helppo korvata sadossa poistunutta fosforia pelkällä karjanlannalla (koejäsen no 5 ja 6 ), sillä naudan lietteessä tuleva typpi rajoitti annettavan fosforinmäärän varsin pieneksi (kokeessa 7-13 kg P/ha/v), mikä oli huomattavasti vähemmän kuin mitattu poistuma. Tähän vaikuttaa ensinnäkin lietteen liukoisen typen määrä, joten lietettä ei voi perustamisvaiheessa käyttää edes kokoviljalle kovin suuria annoksia. Toiseksi lietteen määrää perustamisessa rajoittaa nitraattidirektiivi, joka määrää karjanlannan kokonaistypen ylärajaksi 170 $\mathrm{kg} / \mathrm{ha} / \mathrm{v}$. Edelleen nurmivuosina nurmen pintaan voi levittää vain rajoitettuja määriä, joten karjanlannan tehokas fosforin hyväksikäyttö on ongelmallista.

Mikäli maan fosforitila lasketaan lähelle välttävää, kestää yli kymmenen vuotta, ennen kuin P-tila saadaan taas nostetuksi tasolle tyydyttävä-hyvä. Heikon P-luvun maat eivät muutu viljaviksi suurillakaan fosforimäärillä (Saarela 2002). Tällöin nurmiviljelyä on jatkettava pintalannoituksen turvin.

Fosforiköyhän maan pintalannoitus ei kuitenkaan enää riitä vastaamaan pintakerroksen alla olevien juurien fosforintarvetta haaroittuakseen tehokkaaseen ravinteiden käyttöön ja laadukkaaseen satoon. On tunnettua, että juuret tarvitsevat fosforia haaroittuakseen mutta etäisyys juuren ja fosforin välillä ei saa olla suuri, jotta fosfori päätyy juureen (De Willigen and Van Noordwijk, 1994; Saarela and Saarela 2000). Fosforin ottoon riittää nurmimaassa juuria, jos niillä on edellytykset haaroittua pintaa syvemmälle. Nurmien juuristo on tyypillisesti puolet suurempi kuin viljojen ja suuri osa (60-70\%) juuristosta sijoittuu 0-30 cm:n syvyyteen (Steen 1989). 


\section{Johtopäätökset}

Laadukas nurmisato tarvitsee rakennusaineensa. Hyvärakenteisella maalla fosforitilan ollessa hyvä, on mahdollista tinkiä fosforilannoituksesta muutamien vuosien ajan. Tämä johtaa maan fosforitilan alenemiseen sekä pinta- että kyntökerroksessa. Tämä on hyödyllistä silloin, kun lohkolta huuhtoutuvaa fosforia halutaan vähentää. Maan fosforitilaa ei kuitenkaan kannattane päästää niin alhaiseksi, että nurmi tarvitsisi pintafosforilannoituksen joka vuosi, sillä pintaa annettu lannoitefosfori on alttiina huuhtoutumiselle. Jotta lannan tai lannoitteiden ravinteet saadaan perille kasviin eikä vesien vietäväksi, fosfori tulisi sijoittaa kasvavaan nurmeen. Teknisiä mahdollisuuksia lannoitteen sijoittamiseksi parin sentin syvyydelle on olemassa. Tutkimuksemme laajenee nurmen sijoituslannoituksen käytännön testauksiin ja ympäristövaikutuksiin. Uusien tekniikoiden myötä maan rakenteeseen on muistettava kiinnittää huomiota edelleenkin: Suuret lietevaunut, raskas korjuukalusto ja intensiivinen laidunnus tuhoavat maan huokosten toimivuuden, mikä johtaa pintavaluntaan. Pintavalunta johtaa aina liukoisen fosforin huuhtoutumiseen kasviaineksesta vaikka maan fosforivarastot olisivat tyhjät ja/tai maata ei lannoitettaisi ollenkaan.

\section{Kirjallisuus}

De Willigen, P. \& van Noordwijk, M. 1994. Mass flow and diffusion of nutrients to a root with constant or zerosink uptake. II. Zero-sink uptake. Soil Science 157: 171-175.

MTT 2006. Rehutaulukot ja ruokintasuositukset 2006. Märehtijät - siat - siipikarja - turkiseläimet - hevoset- MTT:n selvityksiä 106. MTT, 84 s.

Räty, M., Uusi-Kämppä, J., Yli-Halla, M., Rasa, K. \& Pietola, L. 2009. Phosphorus and nitrogen cycles in the vegetation of differently managed buffer zones. Nutrient Cycling in Agroecosystems. DOI 10.1007/s10705-0099277-4.

Saarela, I., Järvi, A., Hakkola, H. \& Rinne, K. 1995. Maatalouden tutkimuskeskuksen tiedote 16/95.

Saarela, I., \& Saarela, K. 2000. Mapping spatial variation of diffusible soil P by in situ colouring in Fe-Oxide paper. Comm. Soil Sci. Pl. Anal. 31: 2019-2025.

Saarijärvi, K., Karppinen, M., Uusi-Kämppä, J., Turtola, E., \& Virkajärvi, P., 2006. Laitumen fosforitalous ja vesistökuormituksen hallinta. Teoksessa: Laura Alakukku (toim.). Maaperän prosessit - pellon kunnon ja ympäristönhoidon perusta: MMM:n maaperätutkimusohjelman loppuraportti. Maa- ja elintarviketalous 82: 23-32.

Sippola, J. \& Saarela, I. 1992. Suomen maalajien fosforinpidätysominaisuudet ja niiden merkitys vesien kuormituksen kannalta. Vesi- ja ympäristöhallituksen monistesarja 359: 27-36.

Steen, E. 1989. Root biomass in timothy and red clover leys estimated by soil coring and mesh bags. J. Agric. Sci., Cambridge 113: 241-247.

Turtola, E. \& Yli-Halla, M. 1999. Fate of phosphorus applied in slurry and mineral fertilizer: accumulation in soil and release into surface runoff water. Nutrient Cycling in Agroecosystems 55: 165-174.

Uusi-Kämppä, J., Braskerud, B., Jansson, H., Syversen, N. \& Uusitalo, R. 2000. Buffer zones and constructed wetlands as filters for agricultural phosphorus. Journal of Environmental Quality 29: 151-158. 